\title{
Effect of a Randomised Controlled Vitamin D Trial on Insulin Resistance and Glucose Metabolism in Patients with Type 2 Diabetes Mellitus
}

Authors

Affiliations
F. Strobel ${ }^{1 *}$, J. Reusch ${ }^{*}$, M. Penna-Martinez ${ }^{*}$, E. Ramos-Lopez ${ }^{1}$, E. Klahold ${ }^{1}$, C. Klepzig ${ }^{2}$, J. Wehrle ${ }^{3}$, H. Kahles ${ }^{1 *}$, K. Badenhoop ${ }^{1 *}$

${ }^{1}$ Division of Endocrinology, Diabetes and Metabolism, Department of Internal Medicine I, Goethe-University Hospital, Frankfurt am Main, Germany

${ }^{2}$ Diabetes Outpatient Clinic Offenbach and Frankfurt am Main, Germany

${ }^{3}$ Pharmacy of the Goethe-University Hospital, Frankfurt am Main, Germany

Key words
diabetes
vitamin D
metabolism
HbA1c
C-peptide
insulin

received 22.04.2013 accepted 26.09.2013

Bibliography

DOI http://dx.doi.org/

10.1055/s-0033-1358453

Published online:

November 6, 2013

Horm Metab Res 2014;

46: 54-58

(c) Georg Thieme Verlag KG

Stuttgart · New York

ISSN 0018-5043

\section{Correspondence}

Dr. M. Penna-Martinez

Division of Endocrinology,

Diabetes and Metabolism

Department of Internal

Medicine I

Goethe-University Hospital

Frankfurt am Main

Theodor-Stern-Kai 7

60590 Frankfurt am Main

Germany

Tel.: +49/69/630183977

Fax: +49/69/630183343

Marissa.Penna-Martinez@

kgu.de

\section{Abstract}

$\nabla$

The aim of our study was to investigate the influence of a 6-month vitamin D supplementation in patients with noninsulin-requiring type 2 diabetes mellitus. We included 86 patients in a placebo-controlled, randomised, double-blind study. During 6 months patients received Vigantol oil once a week corresponding to a daily dose of 1904 IU or placebo oil, followed by 6 months of follow-up. At start and at 3-month intervals 250HD, PTH, body mass index, HbA1c, insulin, C-peptide, and homeostasis model assessmentindex were measured. The primary outcome was a change in fasting blood glucose and insulin levels. After 6 months of therapy, the verum group's $250 H D$ had increased to a median of $35 \mathrm{ng} / \mathrm{ml}$ in comparison to the placebo group (median $\left.20 \mathrm{ng} / \mathrm{ml}, \mathrm{p}<10^{-6}\right)$. PTH tended to decrease in the

\section{Introduction}

According to the International Diabetes Federation, more than 300 million people worldwide are currently affected by diabetes mellitus (http://www.idf.org/diabetesatlas/5e/the-globalburden). A further increase of diabetes prevalence is expected, in particular due to the growing population in developing countries, the increasing industrialisation, urbanisation, and life style changes [1,2]. Diabetes pathophysiology is believed to result from environmental factors on a genetic background, but the causal genes remain complex and exert low hazard risk ratios [3]. The prevalence of type 2 diabetes (T2D) is influenced by multiple environmental factors, one of them may lie in the vitamin D system [4]. During recent years, vitamin D (VD), mainly known for its effects on bone and mineral metabolism, is growingly perceived as a pleiotropic

${ }^{*}$ Equal contribution. verum group ( $25.5 \mathrm{pg} / \mathrm{ml}$ vs. $35.0 \mathrm{pg} / \mathrm{ml}, \mathrm{p}=0.08)$. After 6 months of therapy, 31 patients (78\%) achieved a $250 H D$ concentration of $>20 \mathrm{ng} / \mathrm{ml}$. Their HbA1c was significantly lower at baseline $(\mathrm{p}=0.008)$ and after therapy $(\mathrm{p}=0.009)$ than in patients with $250 \mathrm{HD}$ below $20 \mathrm{ng} / \mathrm{ml}$. C-Peptide, insulin, and HOMA-index did not change significantly in the verum group but fasting insulin was positively correlated with $250 H D$ concentrations after 6 months of therapy in both groups. There were no significant effects of vitamin D with a daily dose of 1904 IU on metabolic parameters in type 2 diabetes. However, the correlative findings of this study suggest a link of the 250HD status and metabolic function in type 2 diabetes. Whether vitamin D therapy with higher doses can improve glucose metabolism needs to be investigated in follow-up trials.

endocrine regulator [5]. The active form of $\mathrm{VD}$, $1 \alpha, 25(\mathrm{OH})_{2} \mathrm{D}$ or calcitriol, is synthesised from precursor cholesterol by metabolic steps in skin, liver, and kidney. The primary metabolite, 250HD, is the most abundant form of VD in blood and therefore established for measuring VD status. Various studies have shown an association of VD status and T2D [6]. Low 250HD is found more often in patients with T2D [7,8] and correlates with a higher risk for T2D $[6,9,10]$. Furthermore, the 250HD serum concentration is negatively associated with components of the metabolic syndrome, such as obesity, hyperglycaemia [11$13]$, and high body mass index (BMI) $[9,14-16]$. Finally, many studies confirmed an inverse correlation between $250 \mathrm{HD}$ and parameters of insulin resistance: fasting glucose, glucose tolerance, insulin levels, and homeostasis model assessment-index (HOMA-I) [17-24]. In addition, interventional studies showed beneficial effects of VD on glucose status, insulin sensitivity, and insulin resistance [25-27]. 
However, other investigations did not confirm these findings. They showed neither an association between VD and components of the metabolic syndrome [28-30] nor an influence of VD on glucose metabolism and T2D [31-33]. These studies are difficult to compare due to heterogeneous cohorts and differing outcome parameters. Furthermore, the effects of VD on metabolism have mainly been studied in nondiabetics. In addition intervention times varied greatly and patients were treated with very different doses of VD or even combinations of VD and calcium. Therefore, the aim of our study was to investigate the influence of a 6-month VD supplementation of $1904 \mathrm{IU} / \mathrm{d}$ on the metabolism in patients with noninsulin-requiring T2D and to find out how many of the treated individuals would normalise their VD status. Hereby we defined VD deficiency as 25OHD concentrations $<20 \mathrm{ng} / \mathrm{ml}$, VD insufficiency $>20 \mathrm{ng} / \mathrm{ml}$ and $<30 \mathrm{ng} /$ $\mathrm{ml}$, the latter being the threshold for VD sufficiency. For group comparisons we divided the verum or placebo treated patients into those with 250HD levels $<20 \mathrm{ng} / \mathrm{ml}$ (deficient) or $>20 \mathrm{ng} /$ $\mathrm{ml}$ (not deficient; encompassing insufficient and sufficient) [34].

\section{Subjects and Methods \\ $\nabla$}

We invited patients with T2D from the city and region of Frankfurt am Main, Germany, to participate in the study. Out of 101 interested individuals, we recruited 86 patients in a randomised, double-blind, placebo-controlled trial: patients with diagnosed T2D aged 18-80 years without VD supplementation for at least 3 months before baseline. Patients who took bisphosphonates, calcimimetics, glucocorticoids, phenytoin, glycosides, or benzodiazepines, or in which therapy with one of these drugs was planned during study time were excluded. Further exclusion criteria were carcinomas, HIV infection, psychiatric diseases affecting participation, renal or hepatic dysfunction, hypercalcaemia, nephrolithiasis, and sarcoidosis. Women were only included if they were not pregnant or breast-feeding and, if premenopausal, with effective double barrier contraception.

At baseline all participants were randomised into parallel groups ( $50 \%$ placebo, $50 \%$ verum). Study time was 12 months for each patient. During the first 6 months the verum group's patients received 20 drops Vigantol oil once a week, corresponding to a daily dose of $1904 \mathrm{IU} / \mathrm{d}$. The placebo group's patients received placebo oil consisting of medium chain triglycerides once a week. This was followed by 6 months of follow-up. Study visits were at 3-month intervals. At each visit body weight, BMI, and blood pressure were recorded. Laboratory investigations included calcium, phosphate, fasting glucose, and HbA1c. Furthermore, 250HD concentrations and 1, $\alpha-250 H D$ were measured by ${ }^{125}$ I-radioimmunoassay. PTH, insulin, and C-peptide were measured by a solid-phase chemiluminescence immunometric assay. Finally the homeostasis model assessment-index (HOMA-I) was calculated by using the formula: HOMA-I= fasting insulin $\mu \mathrm{U} / \mathrm{ml}) \times$ fasting glucose $(\mathrm{mg} / \mathrm{dl}) / 405$.

Main outcome parameters of the trial were changes in blood glucose and insulin levels with HOMA-I over the course of treatment by either verum or placebo. Power calculations indicated that 82 subjects (half treated by verum and half by placebo) will suffice to have more than $80 \%$ power in order to detect a true difference in the means of 1.25 difference for HOMA-I. The calculations were performed by using the program Power and Sample Size Calculations 3.0. [35].
Table 1 Baseline characteristics of patients; age and duration are medians.

\begin{tabular}{|llll}
\hline Characteristics & All patients & Verum & Placebo \\
\hline $\mathrm{n}$ & 86 & 43 & 43 \\
\hline Age (range, years) & $60(30-78)$ & $61(36-78)$ & $60(30-78)$ \\
\hline Men & 48 & 24 & 24 \\
Women & 38 & 19 & 19 \\
\hline Duration of DM (range, years) & $3(1-4)$ & $2(1-4)$ & $3(1-4)$ \\
\hline
\end{tabular}

\section{Statistical analysis}

For statistical analyses, we used the software program BiAS for windows version 9.08. Group comparisons were conducted by using the nonparametric Wilcoxon-Mann-Whitney U-test and the Kruskal-Wallis test. Correlations were measured by using Spearman's rank correlation coefficient. A p-value of $<0.05$ was determined as significant, $\leq 0.11$ as a trend. All vitamin $D$ levels were adjusted according to the season of blood collection by linear regression using a linear model. These calculations were done by using $\mathrm{R}$ software package that is freely available: Frequently asked questions are available from: http://CRAN.Rproject.org/doc/FAQ/R-FAQ.html.

\section{Results \\ $\nabla$ \\ Baseline characteristics}

The median age of the patients ( 38 women, 48 men) was 60 years with a median diabetes duration of $6-10$ years. The patients' baseline characteristics are shown in $\bullet$ Table 1. Out of 86 recruited, 72 patients completed the full study, 39 in the verum and 33 in the placebo group, with 4 patients missing the follow-up period of the last 6 months. The drop-out of 14 patients was not related to medical but personal reasons. These 14 individuals did not differ from the others for the investigated parameters (data not shown). At baseline all patients $(n=86)$ showed a VD deficiency with median 250HD concentration of $11.90 \mathrm{ng} / \mathrm{ml}$.

\section{Clinical and biochemical parameters over the trial period}

After 3 months of VD therapy, the verum group's $(n=40) 250 H D$ concentration had increased to $37.3 \mathrm{ng} / \mathrm{ml}$, after 6 months of therapy the verum group's $(n=40) 250 H D$ had increased to a median of $35 \mathrm{ng} / \mathrm{ml}$, significantly higher than in the placebo group (median $20 \mathrm{ng} / \mathrm{ml}, \mathrm{p}<10^{-6}$, o Table 3). After VD therapy $37 / 40$ (93\%) patients of the verum group achieved 250HD levels of $>20 \mathrm{ng} / \mathrm{ml}$, but only $29 / 40(73 \%)$ reached $250 \mathrm{HD}$ concentration in the sufficient range $(>30 \mathrm{ng} / \mathrm{ml}$ ).

In contrast, the placebo group showed VD deficiency through the entire study period. In addition the 250HD concentrations varied with the seasonal timing of study visits in both groups (0 Fig. 1) that had started in summer/autumn in most patients. Highest 250HD concentrations were measured in summer (placebo) and in autumn (verum), lowest in winter (placebo) and in spring (verum) when patients were in the follow-up phase (data not shown).

The PTH tended $(\mathrm{p}=0.08)$ to decrease more in the verum group until the end of therapy $(\Delta=9.50 \mathrm{pg} / \mathrm{ml})$. No association between PTH and any other parameter was seen. Both, calcium and phosphate were always in the normal range and nearly constant during the study period. All patients showed calcium levels between 


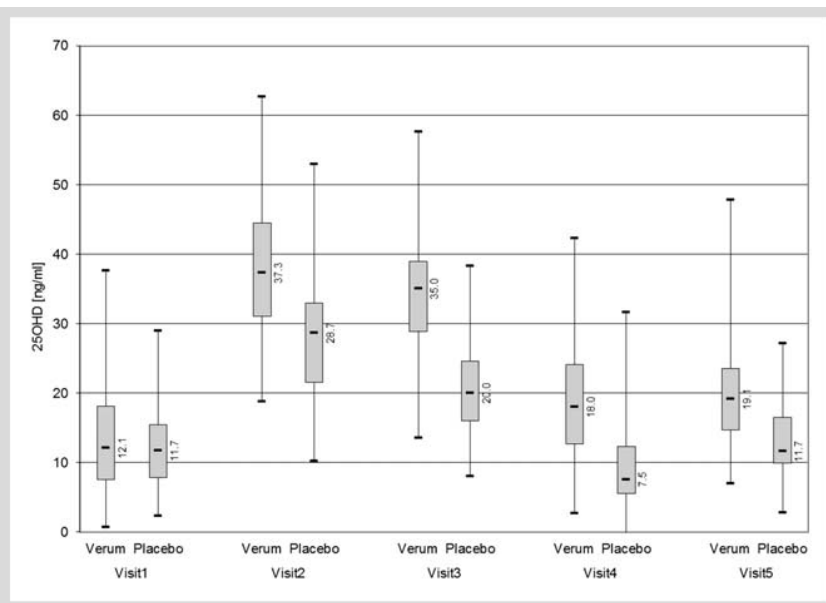

Fig. 1 Median 25OHD concentrations in verum and placebo group.
2.39 and $2.43 \mathrm{mmol} / \mathrm{l}$ and phosphate levels between 3.40 and $3.60 \mathrm{mg} / \mathrm{dl}$.

The study failed to demonstrate a significant effect on the main outcome parameters blood glucose or insulin levels. Neither fasting glucose nor HOMA-I or HbA1C were significantly affected by the intake of Vigantol, nor were there any changes in systolic blood pressure, or body weight. The median systolic blood pressure during whole study time was $140 \mathrm{~mm} \mathrm{Hg}$ in all patients. The verum group's median body weight was $90.4 \mathrm{~kg}$, their fasting glucose $121 \mathrm{mg} / \mathrm{dl}$. In the placebo the median body weight was $83.9 \mathrm{~kg}$, the median fasting glucose $116 \mathrm{mg} / \mathrm{dl}$.

\section{OHD status indicates metabolic control in T2D patients}

In all patients we observed that $25 \mathrm{OHD}$ and BMI were inversely related ( $\odot$ Table 2,4 ) particularly at 6 months of therapy or placebo: those patients with $250 \mathrm{HD}$ levels of $<20 \mathrm{ng} / \mathrm{ml}$ had a median BMI of 33 in comparison to those having achieved a

\begin{tabular}{|l}
\hline $25 O H D(\mathbf{n g} / \mathrm{ml})^{\#}$ \\
PTH $(\mathrm{pg} / \mathrm{ml})$ \\
Body weight $(\mathrm{kg})$ \\
BMI $\left(\mathrm{kg} / \mathrm{m}^{2}\right)$ \\
\hline Systolic blood pressure $(\mathrm{mm} \mathrm{Hg})$ \\
\hline Fasting glucose $(\mathrm{mg} / \mathrm{dl})$ \\
\hline HbA1c $(\mathrm{mmol} / \mathrm{mol} \mathrm{Hb})$ \\
\hline Insulin $(\mu \mathrm{U} / \mathrm{ml})$ \\
\hline HOMA-index $(\mu \mathrm{U} / \mathrm{ml} \times \mathrm{mg} / \mathrm{dl})$ \\
C-Peptide $(\mathrm{ng} / \mathrm{ml})$
\end{tabular}

25OHD (ng/ml)\#

PTH $(\mathrm{pg} / \mathrm{ml})$

Body weight $(\mathrm{kg})$

BMI $\left(\mathrm{kg} / \mathrm{m}^{2}\right)$

Systolic blood pressure $(\mathrm{mm} \mathrm{Hg})$

Fasting glucose (mg/dl)

$\mathrm{HbA1c}(\mathrm{mmol} / \mathrm{mol} \mathrm{Hb})$

Insulin $(\mu \mathrm{U} / \mathrm{ml})$

HOMA-index $(\mu \mathrm{U} / \mathrm{ml} \times \mathrm{mg} / \mathrm{dl})$

C-Peptide $(\mathrm{ng} / \mathrm{ml})$

\#Adjusted for season of blood collection
Baseline values (all patients $n=86$ )

$\leq 20$

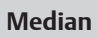

42

Range

$87.1 \quad 55.5-140.1$

21.1-44.1

$110-180$

$69-224$

34-75

2-41

$0.3-14$

$0.6-6.8$
$>20$

Median
34
85.3
28.6
141
117
48
7.7
1.8
2.2

\section{Range}

9.3-103

60-127

21.8-41.5

110-190

90-166.9

$41-54$

2-32

$0.6-11.3$

$1.6-4.6$

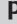

0.352

0.808

0.246

0.548

0.693

0.008

0.969

0.908

0.504

After 6 months of therapy (all patients $n=77$ )

$\leq 20$

Median

32

87.2

33.0

140

118.0

54

4.8

1.2

1.8
Range

16.1-81

61.8-131.5

23-44.4

117-170

87-170

42-81

2-19

$0.4-5.8$

$0.6-4.5$
$>20$

Median

27

85.4

29.9

140

121.0

50

7.8

2.2

2.2

\section{Range}

3.5-74

56-139

21.6-41.5

100-201

60-182

30-64

2-80.2

0.4-8.6

$0.2-9.5$ p

0.152

0.816

0.098

0.932

0.874

0.009

0.111

0.202 0.259
Table 2 Parameters before and after 6 months of VD-therapy in all study subjects classified according to their $250 \mathrm{HD}$ concentration, which were adjusted for season of blood collection.

\begin{tabular}{|llllll|} 
& \multicolumn{2}{c}{ Verum } & \multicolumn{2}{c}{ Placebo } \\
& Median & Range & Median & Range & P \\
\hline 25OHD $(\mathrm{ng} / \mathrm{ml})^{\#}$ & 35 & $13.6-57.6$ & 20 & $8-38.3$ & $<10^{-6}$ \\
\hline PTH $(\mathrm{pg} / \mathrm{ml})$ & 25.5 & $7.8-67$ & 35 & $3.5-81$ & 0.080 \\
\hline Body weight $(\mathrm{kg})$ & 90.4 & $56-139$ & 83.9 & $60-131.5$ & 0.524 \\
\hline BMI $\left(\mathrm{kg} / \mathrm{m}^{2}\right)$ & 30.5 & $21.6-41.5$ & 31.1 & $22.5-44.4$ & 0.856 \\
Systolic blood pressure $(\mathrm{mm} \mathrm{Hg})$ & 140 & $100-201$ & 140 & $117-160$ & 0.955 \\
\hline Fasting glucose $(\mathrm{mg} / \mathrm{dl})$ & 121 & $84-178$ & 119.5 & $60-182$ & 0.624 \\
\hline HbA1c $(\mathrm{mmol} / \mathrm{mol} \mathrm{Hb})$ & 51 & $30-64$ & 51 & $38-81$ & 0.681 \\
\hline Insulin $(\mu \mathrm{U} / \mathrm{ml})$ & 7.5 & $2-80.2$ & 5.6 & $2-27$ & 0.749 \\
\hline HOMA-index $(\mu \mathrm{U} / \mathrm{ml} \times \mathrm{mg} / \mathrm{dl})$ & 1.9 & $0.4-7.8$ & 1.5 & $0.4-8.6$ & 0.821 \\
\hline C-Peptide $(\mathrm{ng} / \mathrm{ml})$ & 2.4 & $0.2-9.5$ & 1.9 & $0.4-6.2$ & 0.553 \\
\hline
\end{tabular}

Table 3 Outcome measures after 6 months of therapy (Visit 3). 


\begin{tabular}{|c|c|c|c|c|c|c|c|c|}
\hline & \multirow{2}{*}{\multicolumn{2}{|c|}{$\begin{array}{c}\text { Baseline values } \\
\text { All patients }(n=86)\end{array}$}} & \multicolumn{6}{|c|}{ After 6 months of therapy (all patients $n=77$ ) } \\
\hline & & & \multicolumn{2}{|c|}{ All patients } & \multicolumn{2}{|c|}{ Verum } & \multicolumn{2}{|c|}{ Placebo } \\
\hline & rho & $\mathbf{p}$ & rho & p & rho & $\mathbf{p}$ & rho & $\mathbf{p}$ \\
\hline PTH (pg/ml) & -0.19 & 0.081 & -0.20 & 0.078 & -0.11 & 0.488 & -0.08 & 0.645 \\
\hline Body weight (kg) & -0.10 & 0.373 & 0.01 & 0.941 & -0.11 & 0.483 & -0.13 & 0.447 \\
\hline BMI $\left(\mathrm{kg} / \mathrm{m}^{2}\right)$ & -0.26 & 0.015 & -0.14 & 0.216 & -0.18 & 0.271 & -0.35 & 0.040 \\
\hline Systolic blood pressure (mm Hg) & 0.03 & 0.799 & 0.00 & 0.993 & -0.10 & 0.558 & 0.19 & 0.273 \\
\hline Fasting glucose (mg/dl) & 0.04 & 0.740 & 0.01 & 0.946 & -0.18 & 0.282 & -0.03 & 0.854 \\
\hline $\mathrm{HbA1c}(\mathrm{mmol} / \mathrm{mol} \mathrm{Hb})$ & -0.23 & 0.038 & -0.19 & 0.089 & -0.19 & 0.245 & -0.31 & 0.064 \\
\hline Insulin $(\mu \mathrm{U} / \mathrm{ml})$ & -0.12 & 0.265 & 0.23 & 0.041 & 0.11 & 0.492 & 0.41 & 0.013 \\
\hline HOMA-index $(\mu \mathrm{U} / \mathrm{ml} \times \mathrm{mg} / \mathrm{dl})$ & -0.10 & 0.357 & 0.19 & 0.106 & -0.01 & 0.954 & 0.36 & 0.030 \\
\hline C-Peptide (ng/ml) & -0.06 & 0.616 & 0.20 & 0.074 & 0.14 & 0.398 & 0.17 & 0.311 \\
\hline
\end{tabular}

Table 4 Correlation of parameters with $250 \mathrm{HD}$ before and after 6 months of VD therapy.
25-OH-D level of $>20 \mathrm{ng} / \mathrm{ml}$ with a median BMI of 29.9; $\mathrm{p}=0.098$ ).

Over all study visits the lowest HbA1c levels were seen in patients with $250 \mathrm{HD}$ of $>20 \mathrm{ng} / \mathrm{ml}$. HbA1c was $4 \mathrm{mmol} / \mathrm{mol} \mathrm{Hb}$ ( $\mathrm{p}=0.008$; Table 2) lower at baseline and $4 \mathrm{mmol} / \mathrm{mol} \mathrm{Hb}$ $(\mathrm{p}=0.009$; Table 2) lower after VD therapy than in patients with $250 \mathrm{HD}$ of $<20 \mathrm{ng} / \mathrm{ml}$. Highest HbA1c $(\mathrm{p}=0.009)$ by a median of $54 \mathrm{mmol} / \mathrm{mol}$ was seen in patients with $250 \mathrm{HD}$ of $\leq 20 \mathrm{ng} / \mathrm{ml}$ at the end of therapy. As depicted in 8 Table 2 all patients with $250 \mathrm{HD}$ of $>20 \mathrm{ng} / \mathrm{ml}$ showed higher C-peptide $(2.2 \mathrm{ng} / \mathrm{ml}$ vs. $1.8 \mathrm{ng} / \mathrm{ml})$ and higher insulin $(7.8 \mu \mathrm{U} / \mathrm{ml}$ vs. $4.8 \mu \mathrm{U} /$ $\mathrm{ml}, \mathrm{p}=0.11$ ) after VD therapy, but this was not significant. However 250HD concentrations correlated significantly with the BMI at baseline in all patients and after 6 months of therapy in the placebo group. Furthermore fasting insulin was positively correlated with 25OHD after 6 months of therapy in both groups (॰ Table 4).

\section{Discussion and Conclusion}

Vitamin D deficiency or insufficiency is highly prevalent and this observation is more profound in patients with type 2 diabetes $[36,37]$. This global epidemic has been described in several populations of all age groups and evoked interest into the effects of controlled vitamin D supplementation as opposed to uncontrolled self-ingestion as an alimentary component. It is now widely held that vitamin D has multiple extra-skeletal effects, some of which affect metabolism and the endocrine pancreas [38]. In an animal model active vitamin D can increase islet insulin secretion upon glucose stimuli [39].

Whether vitamin $\mathrm{D}$ can also affect the human $\beta$-cell has been subject to several studies, including interventional trials. A meta-analysis of vitamin D supplementation of patients with type 2 diabetes has recently summarised 15 trials that had included patients for a controlled intervention with vitamin $D$, its metabolites and placebo, and studied fasting glucose, HbA1c as well as parameters of insulin resistance [40]. The conclusion of their summary was that insufficient evidence supported a recommendation for vitamin D supplementation for improving glucose metabolism or insulin action in patients with diabetes or prediabetes. However, those studies had used both low vitamin D doses as well as higher ones, had been performed on heterogeneous cohorts, and did not address all potential confounders. Furthermore vitamin D acts on several cells and tissues including immunity. Hereby anti-inflammatory effects may indirectly improve cardiovascular and metabolic health in patients with diabetes [38]. Since vitamin D's immune effects may vary between individuals with variants in their vitamin D system genotypes, intervention trials are needed to address pharmacogenomic differences for potential therapeutic stratification [41].

Our study shows a significantly lower HbA1c with improving 250HD status. Furthermore, this randomised, placebo-controlled intervention study with nearly 2000 IU cholecalciferol per day demonstrates that insulin levels correlate significantly after 6 months of VD although the underlying insulin resistance persisted. Although the trial failed to meet endpoints for improved insulin and C-peptide secretion as well as HOMA-index, the correlation of BMI, HbA1c, insulin levels, and the vitamin D status suggests that glucose homeostasis may be positively regulated by vitamin $\mathrm{D}$. The paradox observation that differences were more significant at 6 months of therapy in the placebo group suggests that either the chosen dose is insufficient or that other factors regulate vitamin D's metabolic effects. A recent placebocontrolled trial with 47 diabetic patients and a lower daily dose ( $1000 \mathrm{IU} / \mathrm{d})$ demonstrated no metabolic effects but a nonsignificant increase in adiponectin and a significant improvement of aortal stiffness [42].

Physiologic and metabolic improvement may be due to direct or indirect VDR-mediated musculoskeletal, hepatic or effects on pancreatic $\beta$-cell secretion. Since $\beta$-cells express the VDR, some of their pathways involved in insulin secretion are subject to VD actions such as metabolic processing, stress response and DNA repair, as well as epigenetic regulations. These mechanisms have recently been elucidated by microarray analysis of buffy coat cells from a small randomised double-blind clinical trial using $2000 \mathrm{IU}$ VD/d [43].

Since vitamin $\mathrm{D}$ dosing appears to be safe in this population of preadipose and obese individuals higher VD doses are needed to optimise VD status in more than half of patients. Interventional studies with higher study numbers and higher VD doses are required to verify these findings. However, this study illustrates potential metabolic benefits of VD therapy in type 2 diabetes.

\section{Acknowledgements \\ $\nabla$}

Vigantol oil was provided by Merck KGaA. We thank Dr. Ulrike Hostalek for continuous support. KB received a grant based on the EU-FP7 program (NAIMIT, grant agreement No. 241447). 


\section{Conflict of Interest}

$\nabla$

The authors declare that there is no conflict of interest that could be perceived as prejudicing the impartiality of the research reported.

\section{References}

1 Guariguata L, Whiting $D$, Weil C, Unwin $N$. The International Diabetes Federation diabetes atlas methodology for estimating global and national prevalence of diabetes in adults. Diabetes Res Clin Pract 2011; 94: 322-332

2 Guariguata L. By the numbers: new estimates from the IDF Diabetes Atlas Update for 2012. Diabetes Res Clin Pract 2012; 98: 524-525

3 Andersson EA, Allin KH, Sandholt CH, Borglykke A, Lau CJ, Ribel-Madsen R, Sparso T, Justesen JM, Harder MN, Jorgensen ME, Jorgensen T, Hansen T, Pedersen 0 . Genetic risk score of 46 type 2 diabetes risk variants associates with changes in plasma glucose and estimates of pancreatic betacell function over five years of follow-up. Diabetes 2013; 62: 3610-3617

4 Pittas AG, Nelson J, Mitri J, Hillmann W, Garganta C, Nathan DM, Hu FB, Dawson Hughes B. Plasma 25-hydroxyvitamin D and progression to diabetes in patients at risk for diabetes: an ancillary analysis in the Diabetes Prevention Program. Diabetes Care 2012; 35: 565-573

5 Van Belle TL, Gysemans C, Mathieu C. Vitamin D and diabetes: the odd couple. Trends Endocrinol Metab 2013 [Epub ahead of print]

6 Pittas AG, Lau J, Hu FB, Dawson-Hughes B. The role of vitamin D and calcium in type 2 diabetes. A systematic review and meta-analysis. J Clin Endocrinol Metab 2007; 92: 2017-2029

7 Hintzpeter B, Mensink GB, Thierfelder W, Muller MJ, Scheidt-Nave C. Vitamin D status and health correlates among German adults. Eur J Clin Nutr 2008; 62: 1079-1089

8 Isaia G, Giorgino R, Adami S. High prevalence of hypovitaminosis D in female type 2 diabetic population. Diabetes Care 2001; 24: 1496

9 Mattila C, Knekt P, Mannisto S, Rissanen H, Laaksonen MA, Montonen J, Reunanen A. Serum 25-hydroxyvitamin D concentration and subsequent risk of type 2 diabetes. Diabetes Care 2007; 30: 2569-2570

10 Pittas AG, Dawson-Hughes B, Li T, Van Dam RM, Willett WC, Manson $J E, H u F B$. Vitamin $D$ and calcium intake in relation to type 2 diabetes in women. Diabetes Care 2006; 29: 650-656

11 Ford ES, Ajani UA, McGuire LC, Liu S. Concentrations of serum vitamin $\mathrm{D}$ and the metabolic syndrome among U.S. adults. Diabetes Care 2005; 28: $1228-1230$

12 Hypponen E, Boucher BJ, Berry DJ, Power C. 25-hydroxyvitamin D, IGF1 , and metabolic syndrome at 45 years of age: a cross-sectional study in the 1958 British Birth Cohort. Diabetes 2008; 57: 298-305

13 Parikh SJ, Edelman M, Uwaifo GI, Freedman RJ, Semega-Janneh M, Reynolds J, Yanovski JA. The relationship between obesity and serum 1,25-dihydroxy vitamin D concentrations in healthy adults. J Clin Endocrinol Metab 2004; 89: 1196-1199

14 Lagunova Z, Porojnicu AC, Lindberg F, Hexeberg S, Moan J. The dependency of vitamin $D$ status on body mass index, gender, age and season. Anticancer Res 2009; 29: 3713-3720

15 McGill AT, Stewart JM, Lithander FE, Strik CM, Poppitt SD. Relationships of low serum vitamin D3 with anthropometry and markers of the metabolic syndrome and diabetes in overweight and obesity. Nutr J 2008; 7: 4

16 Rueda S, Fernandez-Fernandez C, Romero F, Martinez de OJ, Vidal J. Vitamin D, PTH, and the metabolic syndrome in severely obese subjects. Obes Surg 2008; 18: 151-154

17 Alvarez JA, Ashraf AP, Hunter GR, Gower BA. Serum 25-hydroxyvitamin $\mathrm{D}$ and parathyroid hormone are independent determinants of wholebody insulin sensitivity in women and may contribute to lower insulin sensitivity in African Americans. Am J Clin Nutr 2010; 92: 1344-1349

18 Cheng S, Massaro JM, Fox CS, Larson MG, Keyes MJ, McCabe EL, Robins SJ, O'Donnell CJ, Hoffmann U, Jacques PF, Booth SL, Vasan RS, Wolf M, Wang TJ. Adiposity, cardiometabolic risk, and vitamin D status: the Framingham Heart Study. Diabetes 2010; 59: 242-248

19 Chiu KC, Chu A, Go VL, Saad MF. Hypovitaminosis D is associated with insulin resistance and beta cell dysfunction. Am J Clin Nutr 2004; 79: $820-825$

20 Forouhi NG, Luan J, Cooper A, Boucher BJ, Wareham NJ. Baseline serum 25-hydroxy vitamin d is predictive of future glycemic status and insulin resistance: the Medical Research Council Ely Prospective Study 1990-2000. Diabetes 2008; 57: 2619-2625

21 Kayaniyil S, Vieth R, Retnakaran R, Knight JA, Qi Y, Gerstein HC, Perkins $B A$, Harris SB, Zinman B, Hanley AJ. Association of vitamin D with insulin resistance and beta-cell dysfunction in subjects at risk for type 2 diabetes. Diabetes Care 2010; 33: 1379-1381
22 Liu E, Meigs JB, Pittas AG, McKeown NM, Economos CD, Booth SL, Jacques $P F$. Plasma 25-hydroxyvitamin dis associated with markers of the insulin resistant phenotype in nondiabetic adults. J Nutr 2009; 139: 329-334

23 Scragg R, Sowers M, Bell C. Serum 25-hydroxyvitamin D, diabetes, and ethnicity in the Third National Health and Nutrition Examination Survey. Diabetes Care 2004; 27: 2813-2818

24 Zhao G, Ford ES, Li C. Associations of serum concentrations of 25-hydroxyvitamin $\mathrm{D}$ and parathyroid hormone with surrogate markers of insulin resistance among U.S. adults without physician-diagnosed diabetes: NHANES 2003-2006. Diabetes Care 2010; 33: 344-347

25 Pittas AG, Harris SS, Stark PC, Dawson-Hughes B. The effects of calcium and vitamin D supplementation on blood glucose and markers of inflammation in nondiabetic adults. Diabetes Care 2007; 30: 980-986

26 Sabherwal S, Bravis V, Devendra D. Effect of oral vitamin D and calcium replacement on glycaemic control in South Asian patients with type 2 diabetes. Int J Clin Pract 2010; 64: 1084-1089

27 von Hurst PR, Stonehouse W, Coad J. Vitamin D supplementation reduces insulin resistance in South Asian women living in New Zealand who are insulin resistant and vitamin $\mathrm{D}$ deficient $-\mathrm{a}$ randomised, placebo-controlled trial. Br J Nutr 2010; 103: 549-555

28 Hjelmesaeth J, Hofso D, Aasheim ET, Jenssen T, Moan J, Hager H, Roislien $J$, Bollerslev J. Parathyroid hormone, but not vitamin D, is associated with the metabolic syndrome in morbidly obese women and men: a cross-sectional study. Cardiovasc Diabetol 2009; 8: 7

29 Lippi G, Montagnana M, Targher G, Guidi GC. Vitamin D, parathyroid hormone levels, and the prevalence of metabolic syndrome in community-dwelling older adults: response to Reis et al. Diabetes Care 2007; 30: e135

30 Snijder M, van DR, Visser M, Deeg D, Seidell J, Lips P. To: Mathieu C, Gysemans C, Giulietti A, Bouillon R (2005) Vitamin D and diabetes. Diabetologia 48: 1247-1257. Diabetologia 2006; 49: 217-218

31 Avenell A, Cook JA, MacLennan GS, McPherson GC. Vitamin D supplementation and type 2 diabetes: a substudy of a randomised placebocontrolled trial in older people (RECORD trial, ISRCTN 51647438). Age Ageing 2009; 38: 606-609

32 de Boer IH, Tinker LF, Connelly S, Curb JD, Howard BV, Kestenbaum B, Larson JC, Manson JE, Margolis KL, Siscovick DS, Weiss NS. Calcium plus vitamin $D$ supplementation and the risk of incident diabetes in the Women's Health Initiative. Diabetes Care 2008; 31: 701-707

33 Luo C, Wong J, Brown M, Hooper M, Molyneaux L, Yue DK. Hypovitaminosis D in Chinese type 2 diabetes: lack of impact on clinical metabolic status and biomarkers of cellular inflammation. Diab Vasc Dis Res 2009; 6: 194-199

34 Holick MF. Vitamin D deficiency. N Engl J Med 2007; 357: 266-281

35 Dupont WD, Plummer WD Jr. Power and sample size calculations. A review and computer program. Control Clin Trials 1990; 11: 116-128

36 Joergensen C, Gall MA, Schmedes A, Tarnow L, Parving HH, Rossing P. Vitamin D levels and mortality in type 2 diabetes. Diabetes Care 2010; 33: 2238-2243

37 Grimnes G, Emaus N, Joakimsen RM, Figenschau Y, Jenssen T, Njolstad I, Schirmer H, Jorde R. Baseline serum 25-hydroxyvitamin D concentrations in the Tromso Study 1994-95 and risk of developing type 2 diabetes mellitus during 11 years of follow-up. Diabet Med 2010; 27: $1107-1115$

38 Badenhoop K, Kahles H, Penna-Martinez M. Vitamin D, immune tolerance, and prevention of type 1 diabetes. Curr Diab Rep 2012; 12: 635-642

39 Cheng Q Li YC, Boucher BJ, Leung PS. A novel role for vitamin D: modulation of expression and function of the local renin-angiotensin system in mouse pancreatic islets. Diabetologia 2011; 54: 2077-2081

40 George PS, Pearson ER, Witham MD. Effect of vitamin D supplementation on glycaemic control and insulin resistance: a systematic review and meta-analysis. Diabet Med 2012; 29: e142-e150

41 Rose K, Penna-Martinez M, Klahold E, Karger D, Shoghi F, Kahles H, Bayer M, Hintermann E, Pfeilschifter JM, Badenhoop K, Ramos-Lopez E, Christen $U$. Influence of the vitamin D plasma level and vitamin D-related genetic polymorphisms on the immune status of patients with type 1 diabetes: a pilot study. Clin Exp Immunol 2013; 171: 171-185

42 Breslavsky A, Frand J, Matas Z, Boaz M, Barnea Z, Shargorodsky M. Effect of high doses of vitamin D on arterial properties, adiponectin, leptin and glucose homeostasis in type 2 diabetic patients. Clin Nutr 2013 [Epub ahead of print]

43 Hossein-Nezhad A, Spira A, Holick MF. Influence of vitamin d status and vitamin $\mathrm{d} 3$ supplementation on genome wide expression of white blood cells: a randomized double-blind clinical trial. PLoS One 2013; 8: e58725 